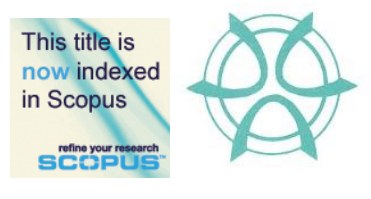

PLANNING MALAYSIA:

Journal of the Malaysian Institute of Planners

VOLUME 16 ISSUE 3 (2018) Page 308 - 319

\title{
MEETING HOUSING NEEDS OF THE POOR AND NEEDY MUSLIMS THROUGH ZAKAT AND WAKAF
}

\author{
Khairuddin Abdul Rashid ${ }^{1}$, Puteri Nur Farah Naadia Mohd Fauzi ${ }^{2}$, \& \\ Sharina Farihah Hasan ${ }^{3}$
}

\author{
Kulliyyah of Architecture and Environmental Design \\ INTERNATIONAL ISLAMIC UNIVERSITY MALAYSIA
}

\begin{abstract}
Meeting housing needs of the poor and needy is a continuous challenge. The challenge is exacerbated, among others, by the continuous and upward increases in the cost of living, population growth and the availability of resources. The Government intervenes through policy implementation and assistance in the forms of subsidies and the provision of social housing. In Islam, there is an opportunity to help the poor and needy meeting their housing needs through zakat and wakaf. Consequently, a study applying a combination of library research and in-depth face-to-face interviews with experts was carried out. The key objectives of the study are to assess the potential of zakat and wakaf in the provision of affordable housing for the poor and needy, and if so, to identify appropriate strategies to empower the zakat and wakaf authorities in carrying out the task. The main findings from the study suggest that zakat and wakaf have great potential to help the poor and needy in meeting their housing needs and that the best way forward is for the zakat and wakaf authorities to do so through collaboration, either among themselves or with private property developers. The significance of the study and its findings are viewed in terms of the innovative idea in promoting zakat and wakaf authorities to collaborate instead of working on their own, with conditions that issues related to the Shariah are resolved.
\end{abstract}

Keywords: economy, housing, procurement, social, wakaf, zakat 
PLANNING MALAYSIA

Journal of the Malaysia Institute of Planners (2018)

\section{INTRODUCTION}

The problem of the poor and needy accessing to or owning decent and affordable housing is on the rise. Despite Government intervention, through a variety of assistance and policy implementations, the housing woes of the poor and needy continues unabated (Abdul Rashid, Ahmad Sarkawi, \& Hasan, 2014; Abdul Rashid, Hasan, Ahmad Sarkawi, Othman, \& Aripin, 2015a; Abdul Rashid, Hasan, \& Ahmad Sarkawi, 2015b; Abdul Rashid et al., 2017; KRI, 2015; Ahmad Sarkawi, Abdul Rashid, \& Hasan, 2015; Cheah \& Almeida, 2016; Abdul Rashid, 2017). Having access to decent and affordable housing is a pre-requisite for nurturing healthy living and good individual and family values (Quran, 30: 21), these values, in turn, contribute towards the overall goodness of society and the country.

The terms poor and needy (miskin and miskin tegar) mean different things to different people. The Government refers to miskin or poor and miskin tegar or needy/hardcore poor as those with monthly household income below RM940.00 and RM580.00 (Peninsular Malaysia) respectively ${ }^{\mathrm{i}}$.

The Government has been active and consistent in assisting the poor and needy in meeting their housing needs. They implemented policies, introduced subsidies and provided assistance including the implementation of a variety of affordable housing schemes that attempt to match affordability - assessed through monthly income - and house type and price (Ahmad Sarkawi et al., 2015; Abdul Rashid, 2017). However, the problem of housing the poor and needy is far from over as the shortfall in affordable housing continues to increase (KRI, 2015; Cheah \& Almeida, 2016; Abdul Rashid, 2017).

In Islam, the poor and needy are referred to as fakir and miskin. The former refers to one that has neither material possession nor means of livelihood while the latter is one with insufficient means of livelihood to meet basic needs. Helping the fakir and miskin is an obligation on the rich as well as highly encouraged on all Muslims; the former through zakat and the latter through wakaf. The presence of zakat and wakaf reaffirms Islam's position on the importance of the fair and equitable distribution of wealth among the ummah (Quran, 2:43; 9:60; 2:155, 261). Under zakat, fakir and miskin are eligible to be assisted and their eligibility is determined through haddul kifayah (poverty line under the zakat system) ${ }^{\text {ii }}$.

The Majlis Agama Islam Negeri-Negeri (MAINs or State Islamic Religious Councils) are the authorities entrusted with the administration of zakat and wakaf. MAINs, therefore, have been active in collecting zakat and wakaf contributions as well as their disbursements. Under zakat, disbursements are made to the asnafs while under wakaf the help goes to beneficiaries that have been specifically designated by the Wakeef (donor) ${ }^{\text {iii }}$. The style of assistance includes helping the asnafs and others in meeting their housing needs ${ }^{\mathrm{iv}}$. However, 
Khairuddin Abdul Rashid, Puteri Nur Farah Naadia Mohd Fauzi, \& Sharina Farihah Hasan Meeting Housing Needs of The Poor and Needy Muslims Through Zakat and Wakaf

Abdul Rashid et al. (2014) contended that not much has been done in terms of helping the asnafs and others in meeting their housing needs in a big way.

The purpose of this paper is to report on a study assessing the potential of zakat and wakaf in the provision of affordable housing for the poor and needy. In addition, the study endeavors to identify appropriate strategies to empower the zakat and wakaf authorities in carrying out the task. The study was carried out through review of literature and interviews with selected representatives of zakat and wakaf authorities and key players of the housing industry.

This paper is structured into 6 parts. Part 1 introduces the paper. Part 2 reviews the state of affordable housing in Malaysia focusing on the supply and demand for low-cost housing. The low-cost housing is deemed as the most appropriate housing scheme to match the affordability and lifestyle of the poor and needy as well as generally meeting the operational requirements of zakat and wakaf. Thereafter, part 3 reviews the state of housing assistance provided by zakat and wakaf respectively to the poor and needy, followed by part 4 wherein methodology used for the study is described. Part 5 and 6 present results from the study and the ensuing discussions followed by the concluding remarks respectively.

\section{AFFORDABLE HOUSING ISSUES IN MALAYSIA}

According to KRI (2015), as of 2010, house ownership in Malaysia stood at $72.5 \%$. In addition, the Government's target to deliver 1 million units of affordable housing by 2018 seems difficult to achieve. Up to 31 December 2016 only $20.7 \%$ of the 1 million targeted units were completed. Furthermore, the Government acknowledge the problems they face in housing the nation. Constraints faced include the acute lack of affordability among house buyers, the mismatch between supply and demand which are location specific and the number of agencies involved with housing (Kementerian Kesejahteraan Bandar, Perumahan dan Kerajaan Tempatan, 2017).

Among the most notable Government efforts in the provision of affordable housing is their policy on the development of housing schemes with prices targeted to benefit the low and middle-income earners. Currently, there are eight such schemes targeting those with monthly household incomes from as low as RM750.00 to not exceeding RM15,000.00 (Table 1).

Table 1: Malaysia's Affordable Housing Schemes

\begin{tabular}{llll}
\hline No & \multicolumn{1}{c}{ Housing scheme } & \multicolumn{1}{c}{$\begin{array}{c}\text { Target monthly } \\
\text { household income (RM) }\end{array}$} & House price (RM) \\
\hline 1 & PRIMA $^{\mathrm{a}}$ & $2,500-15,000$ & $100,000-$ \\
& & 400,000 \\
\hline 2 & Perumahan Mampu Milik $^{\text {Pwa }}$ & My Home 1:3,000 - & $50,000-90,000$ \\
& Swasta $^{\mathrm{b}}$ & 4,000 & (Pen. Malaysia) \\
\hline
\end{tabular}


PLANNING MALAYSIA

Journal of the Malaysia Institute of Planners (2018)

\begin{tabular}{|c|c|c|c|}
\hline & & $\begin{array}{l}\text { My Home } 2: 4,001- \\
6,000\end{array}$ & $\begin{array}{l}90,001-170,000 \\
\text { (ditto) }\end{array}$ \\
\hline 3 & $\begin{array}{l}\text { Perumahan Penjawat Awam } \\
\text { Malaysia }^{c}\end{array}$ & $<10,000$ & $90,000-300,000$ \\
\hline 4 & $\begin{array}{l}\text { Program Perumahan Rakyat } \\
(\mathrm{PPR})^{\mathrm{d}}\end{array}$ & $<3,000$ & $\begin{array}{l}30,000-35,000 \\
\text { (Pen. Malaysia) } \\
40,000 \text { (Sabah, } \\
\text { Sarawak) }\end{array}$ \\
\hline 5 & $\begin{array}{l}\text { Rumah Mesra Rakyat } \\
\text { Malaysia }^{\mathrm{e}}\end{array}$ & $750.00-3,000$ & $40,000-65,000$ \\
\hline 6 & RUMAWIP $(\mathrm{KL})^{\mathrm{f}}$ & $<15,000$ & $80,000-300,000$ \\
\hline 7 & Rumah SelangorKu ${ }^{\mathrm{g}}$ & $3,000-10,000$ & $42,000-250,000$ \\
\hline 8 & Rumah Idaman Rakyat ${ }^{\mathrm{h}}$ & $<10,000$ & $<350,000$ \\
\hline \multicolumn{4}{|c|}{$\begin{array}{l}\text { Source: } \\
\text { a PRIMA (2018). } \\
\text { b,d Ministry of Housing \& Local Government }(2018 a, b) . \\
{ }^{c} \text { Perumahan Penjawat Awam Malayia (2018). } \\
{ }^{e} \text { SPNB Mesra Sdn. Bhd. (2018). } \\
{ }^{f} \text { RUMAWIP, Kementerian Wilayah (2018). } \\
{ }^{8} \text { Lembaga Perumahan \& Hartanah Selangor (2018). } \\
{ }^{h} \text { SPNB Idaman Sdn. Bhd. (2018). }\end{array}$} \\
\hline
\end{tabular}

According to Cheah and Joan Almeida (2016), and Cheah Almeida, Shukri and Lim (2017), most Malaysians could not afford to own a house. The problem is worse in urban areas where the median price of houses is very much higher than what is deemed ideal for affordable housing ${ }^{\mathrm{v}}$. They gave three key reasons for the phenomenon: mismatch between supply and demand, the sluggish increase in household income in relation to the increase in house price, and supply of new units that are concentrated on high-cost housing (i.e. house priced $>$ RM250,000.00 per unit). Cheah and Almeida (2016) argued that the housing industry failed to supply sufficient housing units for those in the low and middleincome segments of the society. They estimated the shortfall, in 2014, stood at 960,000 units. Given the trend in population growth and the increase in the number of households (household sizes tend to decrease), they estimated that by 2020 the shortfall in affordable housing to be in the region of 1 million units. In effort to bridge the gap Cheah and Almeida (2016) proposed strategies that include increasing the supply of affordable housing units, lowering the prices of affordable housing through innovative techniques such as the use of Industrialized Building Systems (IBS), developing a credible private sector rental market for affordable housing, and to further facilitate developers and home buyers having access to financing for their development and purchases respectively.

The findings of Cheah and Almeida (2016) is consistent with the findings from a study carried out by KRI (2015). In the latter, KRI (2015) found out that 
Khairuddin Abdul Rashid, Puteri Nur Farah Naadia Mohd Fauzi, \& Sharina Farihah Hasan Meeting Housing Needs of The Poor and Needy Muslims Through Zakat and Wakaf

the median price of houses in Malaysia in 2014 was 4.4 times more than the median household income. This translates into a 'seriously unaffordable' housing market. In urban areas like Kuala Lumpur and Penang, the situation is considered 'severely unaffordable' whereby the score stood at 5.4 and 5.2 times median household income respectively. KRI (2015) also reiterated that the problem of affordable housing will get worse in years to come given Malaysia's demographic factors namely continuous increase in population, rapid rate of urbanization and decrease in household size.

However, KRI (2015) argued that current affordable housing strategies that focus on the demand side such as making house financing cheaper or providing subsidies for home buyers and supply-side intervention via direct provision of low-cost houses or subsidizing housing costs are unsuitable as they might drive price increases resulting, among others, in more household debt. Their key solution lies on the supply side i.e. improve the elasticity of housing supply so as to make the supply side of housing more responsive to the needs of all sections of the population. KRI (2015) believe such an approach could be realized through reforming the Malaysian procurement system.

\section{ZAKAT AND WAKAF AND AFFORDABLE HOUSING}

Islam calls for Allah's abundance to be shared in a fair and equitable manner. Thus, those bestowed with wealth are required to help the poor and needy. The wealthier Muslims therefore, are required to pay zakat and are encouraged to make wakaf contributions. Hence, zakat is an obligation (wajib) whereas wakaf is philanthropy (Quran, 2:43; 9:60; 2:155, 261). In the former, Allah decrees the beneficiaries to be the asnafs whereas, in the latter, the beneficiaries are as directed by the Wakeef.

In terms of permissibility of utilizing zakat money for the purpose of investing in socio-economic infrastructures such as the building of low cost housing, the Majma al Fiqh al Islami has decided that it is permissible as long as the investment meets the following conditions: an investment may be undertaken as long as no further demand for zakat monies to be distributed for the purpose of basic sustenance, the zakat money is expended on Shariah compliant activities, the investment is guaranteed whereby the principal, as well as the potential profits, belong to zakat, the investment can be promptly liquidated to meet pressing matters involving the asnafs, detailed feasibility study is required and the investment must be approved by the reigning authority ${ }^{\mathrm{vi}}$. Anwar (1995) provided a detailed explanation of the permissibility and compatibility of channeling accumulated zakat funds into long-term investment for the betterment of the ummah. In addition, Saad, Sawandi and Mohammad (2016) pointed out that during the reign of Caliph Umar Abdul Aziz there was zakat surplus and that the surplus funds were invested in projects that bring benefits to the asnafs. In Malaysia, it was reported by Dahaman, Hussin and Mohd Noor (2015) that the 
fatwa committees of the states of Selangor and Melaka have decreed that investing zakat money is permissible but subject to conditions to ensure the security of the zakat monies are not compromised.

Ahmad Sarkawi et al. (2015) reviewed the style and type of housing assistance provided by zakat to asnafs. From a total of 32 types of zakat assistance, two focus on housing i.e. assistance in repairing, building or payment of a deposit for low-cost houses; and assistance to build a house in collaboration with other agencies.

Abdul Rashid et al. (2017) reviewed records on fatwas concerning the permissibility of wakaf assets to be invested in socio-economic developments including housing. In general, it is permissible but subject to specific instructions issued by the Wakeef. Other conditions include the practice of Istibdal (replacement of the acquired land), ownership of the wakaf land where the development takes place is not transferable, only the usufruct, and that the development must be Shariah compliant.

Studies by Abdul Rashid et al. (2017) and Abdul Rashid (2017) revealed that housing projects, both to unlock the value of wakaf land and building lowcost housing, have been commissioned and are currently being commissioned on wakaf land under a variety of procurement approaches. However, on low cost housing Abdul Rashid et al. (2017) identified the reasons why the wakaf authorities are not active: constraints in the availability of wakaf land as suitable sites, inappropriate size of available wakaf land, lack of money as capital, the reluctance of private developers and funders to collaborate in developing affordable housing on wakaf land, and the preference of some wakaf authorities to focus developing traditional religious facilities rather than low cost housing, arguing instead that housing is a State matter.

On the constraints faced by wakaf authorities in developing wakaf land for housing, researchers have proposed that wakaf should consider working in collaboration with others such as with zakat and/or private property developers ${ }^{\text {vii }}$. For example, in a study carried out by Mohd Ali et al. (2016), they highlighted the merits when zakat and wakaf collaborate in the building of residential units for asnafs. Similarly, Abdul Rashid et al. (2014; 2015a) proposed a tripartite joint venture procurement model between wakaf-zakat-private property developer as a way forward.

\section{METHODOLOGY}

In the current study, the authors hypothesized that zakat and wakaf have great potential in contributing towards the provision of affordable housing for the poor and needy. They believe that these two socio-economic instruments could be utilized as the third funding source - self-funding and State's funding via appropriate policies, subsidies and social housing being the first two funding sources respectively - in helping the poor and needy towards meeting their 
Khairuddin Abdul Rashid, Puteri Nur Farah Naadia Mohd Fauzi, \& Sharina Farihah Hasan Meeting Housing Needs of The Poor and Needy Muslims Through Zakat and Wakaf

housing needs. Consequently, the key objective set for the study is to assess the potential of zakat and wakaf in the provision of affordable housing for the poor and needy. In addition, this study endeavors to identify appropriate strategies to empower the zakat and wakaf authorities in carrying out the task.

The study adopted the qualitative research method. It combined desk research - review of the literature including fatwas on zakat and wakaf - and a series of open-ended face-to-face interviews with representatives drawn from 6 zakat and wakaf authorities (MAINs) and 4 housing developers involved in developing housing projects on wakaf land.

\section{RESULTS AND DISCUSSIONS}

In the course of the study, 10 interviews were conducted. The interviews generated rich qualitative data that was analyzed using the thematic analysis technique. Table 2 presents the results of the study.

Table 2: Results from the interviews

\begin{tabular}{|c|c|c|c|}
\hline $\begin{array}{l}\text { Provision of housing } \\
\text { for the poor and } \\
\text { needy }\end{array}$ & Zakat & Wakaf & Strategy \\
\hline Shariah permissibility & Yes & Yes & $\begin{array}{l}\text { Zakat with conditions } \\
\text { Wakaf as desired by the Wakeef }\end{array}$ \\
\hline $\begin{array}{l}\text { Preferred type of } \\
\text { housing }\end{array}$ & $\begin{array}{l}\text { Low- } \\
\text { Cost } \\
\text { Housing }\end{array}$ & $\begin{array}{l}\text { Low- } \\
\text { Cost } \\
\text { Housing }\end{array}$ & $\begin{array}{l}\text { Type and price to follow the } \\
\text { Government's Low-Cost Housing }\end{array}$ \\
\hline $\begin{array}{l}\text { Priority in solving the } \\
\text { housing issue }\end{array}$ & $\mathrm{X}$ & $\mathrm{X}$ & $\begin{array}{l}\text { To solve peoples' problems related to } \\
\text { well-being, religion, education and } \\
\text { the likes. Housing is a State matter }\end{array}$ \\
\hline \multicolumn{4}{|l|}{ Capability } \\
\hline Land & $\mathrm{X}$ & Yes & $\begin{array}{l}\text { Unsuitable/restricted wakaf land } \\
\text { might be swapped via Istibdal }\end{array}$ \\
\hline Capital & Possible & Yes & $\begin{array}{l}\text { Can raise money via cash wakaf, } \\
\text { utilize surplus zakat money }\end{array}$ \\
\hline Expertise & $\mathrm{X}$ & $\mathrm{X}$ & $\begin{array}{l}\text { Willing to collaborate, subject to } \\
\text { Shariah permissibility }\end{array}$ \\
\hline $\begin{array}{l}\text { Forming JV with a } \\
\text { private developer }\end{array}$ & Yes & Yes & $\begin{array}{l}\text { Terms of JV agreement should follow } \\
\text { Shariah }\end{array}$ \\
\hline $\begin{array}{l}\text { Experience working } \\
\text { with a private } \\
\text { developer }\end{array}$ & $\mathrm{X}$ & Yes & \\
\hline $\begin{array}{l}\text { The willingness of } \\
\text { private property } \\
\text { developer }\end{array}$ & Yes & Yes & $\begin{array}{l}\text { Some developers are skeptical. They } \\
\text { could not comprehend the risks due to } \\
\text { potential Shariah issues }\end{array}$ \\
\hline
\end{tabular}


The results from the study suggest that it is permissible, subject to Shariah conditions, for zakat surplus to be used as an investment in socioeconomic projects including the building of houses for the asnafs. Similarly, it is permissible, subject to Shariah conditions, for wakaf to be employed in the provision of affordable housing for the poor and needy. In terms of the type of housing suitable for development, the interviewees agreed that houses to be developed for the poor and needy should be modeled after the Government's Low-Cost Housing Scheme, with the price capped at about RM40,000.00 per unit.

However, both the zakat and wakaf authorities do not feel that the provision of housing for the poor and needy should be accorded the highest priority. They consider looking after the well-being of the poor and needy Muslims especially in the provision of daily sustenance, education, religion and medical and health are more important. In addition, they consider the provision of housing for the poor and needy are matters to be addressed by the State.

In terms of availability of land for development, zakat has no such resource but wakaf has a sizeable land bank scattered across the country. According to Hasan (2008), there was a total of 20,735.61 acres of land registered as wakaf land, comprising 14,815.787 acres for specific wakaf and 5,919.83 acres for general wakaf. Wakaf land designated as specific (other than for housing) cannot be used for housing development unless replaced via Istibdal.

In terms of availability of funding to be used as capital, Ahmad Sarkawi et al. (2015) believe that zakat authorities could utilize zakat surplus i.e. the balance after all disbursements made. In contrast to zakat, wakaf is not cash-rich. However, through initiatives in unlocking the values of wakaf land and effort in collecting cash wakaf, the potential of wakaf being richer in cash looks promising. The cash arising therefrom could be expended as capital for housing development.

However, in terms of expertise, both zakat and wakaf authorities admitted that their organizations are staffed by non-technically trained personnel. Therefore, their capability to handle housing development projects is very limited. In past and on-going projects, they appointed consultants or partnered with Jabatan Kerja Raya Malaysia (JKR).

The respondents view the idea of zakat and wakaf authorities integrating their resources as positive. Results from the review of the literature confirmed that some MAINs have already embarked on such initiatives whereby zakat authorities build facilities intended to benefit the asnafs on wakaf land (Abdul Rashid, 2017). In addition, acknowledging their lack of technical expertise as well as the requirement of a much larger amount of capital injection into mass low-cost housing projects, these authorities are receptive of working with private property developers, on condition that the requirements of the Shariah, are not in any way compromised. 
Khairuddin Abdul Rashid, Puteri Nur Farah Naadia Mohd Fauzi, \& Sharina Farihah Hasan

Meeting Housing Needs of The Poor and Needy Muslims Through Zakat and Wakaf

On the part of the private property developers, most Muslim developers are keen to participate in such collaborative working environment. They believe such an engagement would benefit them in terms of the appropriate profits and also as means of contribution towards the ummah and Islam. However, the small and medium-sized private property developers may face difficulties to acquire the much-needed working capital and bridging finance. Wakaf land could not be monetized. Banks are reluctant to accept wakaf land as collateral since the developers or MAINs do not have outright ownership or rights over the land.

In terms of appropriate strategies that could be employed to combat the identified constraints, topping the list of potential strategies are:

1. Zakat and wakaf authorities should consider collaborating thus, enhancing their financial and technical capabilities to handle housing development projects. To this end, further interpretation of the relevant Shariah rulings on the permissibility of such a collaboration, distribution of risks and responsibilities, and the resulting incomes are required;

2. Capabilities of the zakat and wakaf authorities could be further enhanced, in all the key areas, by working in collaboration with credible private property developers;

3. The zakat and wakaf authorities should consider procuring houses in a variety of styles to suit their funding and technical capabilities and demand for houses by the poor and needy Muslims. Demand should be localized. In this way, small or medium scales procurement could be undertaken that carry lesser risk such as direct purchases from established developers or from the secondary market. Procurement of a new development involving a large amount of funding and other resources are subjected to a higher level of risk and this style of development should not become the mainstream approach.

4. Capacity building within the MAINs and strategic change in mindset are required. The authorities should acknowledge that zakat and wakaf are powerful tools that could be utilized effectively in uplifting the socioeconomic conditions of the Muslims especially the poor and needy, including in meeting their housing needs; and

5. Government support via positive policies is needed and this must be complemented by active $R \& D$ to drive the ideas forward.

\section{CONCLUSION}

This paper reported on a study assessing the potential of zakat and wakaf in the provision of affordable housing for the poor and needy. The findings from the study suggested that zakat and wakaf have such a potential. In addition, the study identified the availability of key resources and mindset of as among the key constraints that could impede upon such a potential. To this end, key strategies that include a call for the zakat and wakat authorities to work in collaboration 
PLANNING MALAYSIA

Journal of the Malaysia Institute of Planners (2018)

with credible private property developers thus enhancing their financial and technical capabilities, and capacity building within the MAINs have been identified and herein recommended for further consideration.

\section{ACKNOWLEDGEMENT}

The study is funded by the Ministry of Higher Education Malaysia: TRGS/1/2016/UIAM/01/3/1. Project ID: TRGS16-01-001-0001. "A Study into Procurement and Project delivery System to Empower Wakaf and Zakat in the Provision of Housing for the Ummah". In addition to the authors, the following are also involved with the study: Assoc. Professor Dr. Azila Ahmad Sarkawi and Assistant Professor Ar. Dr. Srazali Aripin.

\footnotetext{
${ }^{\mathrm{i}}$ Refer to Program Pembasmian Kemiskinan Bandar (PPKB) Kementerian Kesejahteraa Bandar, Perumahan Dan Kerajaan Tempatan, online:

http://www.kpkt.gov.my/index.php/pages/view/285 accessed 13 November 2017.

${ }^{\text {ii }}$ For further discussion on haddul kifayah refer to Manual Pengurusan Agihan Zakat published by Jabatan

Wakaf, Zakat dan Haji, Jabatan Perdana Menteri Malaysia, online:

http://intranet.jawhar.gov.my/penerbitan/p_admin/file_upload/manual_pengurusan_agihan_zakat.pdf accessed

10 February 2018.

iii Refer to JAWHAR, available online: http://intranet.jawhar.gov.my/spmj/public/index.php accessed 11

November 2017.

${ }^{\text {iv }}$ Refer to http://www.zakatselangor.com.my/terkini/fakir-miskin-dapat-bantuan-rumah-lzs-mais/; http://www.maiamp.gov.my/maiamp2/index.php/zakat/maklumat-bantuan-bina-rumah.html;

https://selangorkini.my/2015/12/mais-tiga-tanah-wakaf-bangunkan-projek-perumahan/; all accessed 11 November 2017.

${ }^{\mathrm{v}}$ The authors used the Median Multiple (MM) approach, i.e. maximum median house price is 3 times the annual median household income. In their study, they found out that the ratio of housing affordability in 2014 stood at 4.4 which means houses in Malaysia is seriously unaffordable (Cheah Su Ling and Joan Almeida, 2016).

${ }^{\text {vi }}{ }^{\text {rd }}$ Seminar Majma al Fiqh al Islami held on 8-9 Jamadil Akhir 1413H (2-3 December 1992 in Kuwait as quoted by Azila et al. 2015 .

${ }^{\text {vii }}$ On wakaf development via government funding in collaboration with financial institution and body corporate, see Anan C. Mohd (2015). Pembangunan Wakaf Menerusi Pendanaan Kerajaan dan Kerjasama Institusi Kewangan dan Korporat: Hala Tuju, Cabaran dan Harapan. Presentation, Program Muzakarah Wakaf anjuran JAKIM, Sasana Kijang, Bank Negara Malaysia, 12 November 2015.
}

\section{REFERENCES}

Abdul Rashid, K., Ahmad Sarkawi, A., \& Hasan, S. F. (2014, August). Development of a proposed waqaf-zakat-real estate developer joint venture model to address the issue of affordable housing for the low and middle income Muslim families. World Conference on Islamic Thought and Civilization (The Rise and Fall of Civilization: Contemporary States of Muslim affairs), August 18-19, 2014, Ipoh, Perak,

Abdul Rashid, K., Hasan, S. F., Ahmad Sarkawi, A., Othman, J., \& Aripin, S. (2015a June). Preliminary discussion on the potential of zakat-wakaf collaboration in the provision of housing for the needy Muslims. National Conference on Zakat and Economic Development 2015. June 1, 2015, Kuantan Pahang.

Abdul Rashid, K., Hasan, S. F., \& Ahmad Sarkawi, A. (2015b, November). Assessing the appropriateness and adequacy of the provision for housing under the haddul- 
Khairuddin Abdul Rashid, Puteri Nur Farah Naadia Mohd Fauzi, \& Sharina Farihah Hasan

Meeting Housing Needs of The Poor and Needy Muslims Through Zakat and Wakaf

kifayah for asnaffaqr and asnaf miskin. $3^{\text {rd }}$ ASEAN International Conference on Islamic Finance (AICIF). November 17-19, 2015, Semarang, Indonesia.

Abdul Rashid, K., Hasan, S. F., Mohd Fauzi, P. N. F. N., Ahmad Sarkawi, A., Aripin, S., \& Mansor, N. S. (2017, April). Permissibility of wakaf in the provision of affordable housing. International Conference on Business and Social Science (ICBSS 2017). April 14-15, 2017, Seoul Korea.

Abdul Rashid, K. (2017, September). Sumbangan sektor hartanah wakaf kepada penyelesaian isu perumahan negara. Seminar Wakaf FSPU UiTM 2017. September 20, 2017, Shah Alam, Selangor.

Ahmad Sarkawi, A., Abdul Rashid, K., \& Hasan, S. F. (2015). Penyediaan tempat tinggal golongan asnaf menurut skim bantuan agihan zakat: Cadangan pengunaan tanah wakaf. Jurnal Pengurusan JAWHAR, 9(1).

Anwar, M. (1995). Financing socio-economic development with zakat funds. Journal of Islamic Economics, 4(1\&2), 15-32.

Cheah, S. L., \& Almeida, S. J. (2016). Pencerahan terhadap isu rumah mampu milik di Malaysia. In Bank Negara Malaysia, Laporan Tahunan 2016 (pp. 99-108).

Cheah, S. L., Almeida, S. J., Shukri, M. \& Lim, L. S. (2017). Imbalances in the property market. Bank Negara Malaysia, Quarterly Bulletin, $3^{\text {rd }}$ Quarter 2017, 26-28.

Dahaman, M. A., Hussin, A. M., \& Mohd Noor, M. N. (2015, June). Pengembangan dana Baitulmal Majlis Agama Islam dan Adat Istiadat Melayu Perlis (MAIPs): Amalan dan cabaran. Persidangan Zakat dalam Pembangunan Ekonomi Peringkat Kebangsaan 2015. June 1, 2015, Kuantan, Pahang.

Hasan, Z. (2008, June 15). An overview of the effectiveness of the administration of waqf land in Malaysia. Shariah Law Report, Current Law Journal, 2008. Available at https://ssrn.com/abstract=2234208.

Kementerian Kesejahteraan Bandar, Perumahan dan Kerajaan Tempatan (2017). Siaran Media Keputusan Mesyuarat Majlis Perumahan Negara, 2 Mac 2017. Available at http://www.kpkt.gov.my/index.php/pages/view/508

Khazanah Research Institute [KRI] (2015). Making housing affordable. Kuala Lumpur: Author.

Lembaga Perumahan \& Hartanah Selangor (2018). Rumah Selangorku. Retrieved July 9, 2018 from http://lphs.selangor.gov.my/

Ministry of Housing \& Local Government (2018a). Skim perumahan mampu milik swasta. Retrieved July 9, 2018 from http://ehome.kpkt.gov.my/

Ministry of Housing \& Local Government (2018b). Program Perumahan Rakyat (PPR). Retrieved July 9, 2018 from http://ehome.kpkt.gov.my/

Mohd Ali, S. N., Mohd Noor, A. H., Chuweni, N. N., Ismail, N. R. P., Md Dahlan, F., \& Shari, M. S. A. (2016). Integrating awqaf and zakat: A case study of land development for the poor in the State Islamic Religious Council Terengganu, Malaysia. In S. K. Ab. Manan, F. Abd Rahman, \& M. Sahri (Eds), Contemporary issues and development in the global halal industry (pp. 209217). (n.p.): Springer.

Perumahan Penjawat Awam Malaysia (2018). PPAM. Retrieved July 9, 2018 from https://www.ppa1m.gov.my/

PR1MA (2018). PRIMA, rumahku, komunitiku. Retrieved July 9, 2018 from https://www.pr1ma.my/. 
RUMAWIP, Kementerian Wilayah (2018). RUMAWIP. Retrieved July 9, 2018 from https://rumawip.kwp.gov.my/

Saad, R. A. J., Sawandi, N. F., \& Mohammad, R. (2016). Zakat surplus funds management. International Journal of Economics and Financial Issues, 6(7S), $171-176$.

SPNB Idaman Sdn. Bhd. (2018). Rumah idaman rakyat. Retrieved July 9, 2018 from https://www.spnbidaman.com.my/

SPNB Mesra Sdn. Bhd. (2018). Rumah mesra rakyat Malaysia. Retrieved July 9, 2018 from http://www.spnbmesra.com.my/ 